\title{
In Search of the Elusive Membranous Nephropathy Antigen
}

\author{
David J. Salant \\ Renal Section, Boston University Medical Center, Boston, Mass., USA
}

Work on the Heymann nephritis model of experimental membranous nephropathy (MN) in rats in the Couser and Hoedemaeker labs in the late 1970s established that the characteristic subepithelial immune deposits form in situ [1-3]. The target antigen gp330/megalin was subsequently identified by Kerjaschki and Farquhar $[4,5]$ and shown to reside on rat podocytes; however, megalin is not expressed on human podocytes. Nonetheless, more recent observations by Debiec et al. $[6,7]$ in an alloimmune form of neonatal MN in babies born to mothers with a homozygous deficiency of neutral endopeptidase (NEP) validated the in situ paradigm in human MN. The mothers were sensitized to NEP by a previous pregnancy and developed circulating anti-NEP alloantibodies that crossed the placenta and bound to NEP on the babies' podocytes.

With this background we embarked on a search for the target antigen in idiopathic MN using patient sera and proteins extracted from glomeruli isolated from normal human donor kidneys that were unsuitable for transplantation. On Western blot analysis we found that sera from almost $70 \%$ of patients with idiopathic $\mathrm{MN}$ - but not secondary (lupus and hepatitis B) MN, other proteinuric diseases, or normal controls - had circulating antibodies to a reduction-sensitive glycoprotein that is expressed on normal human podocytes. One might ask: why aren't $100 \%$ positive? It could be the technical limitations of the assay, or that idiopathic MN might not be a uniform disease and may have different antigens. The possibility that
I favor is that antibodies may wax and wane with disease activity during the clinical course, and the presence of proteinuria in $\mathrm{MN}$ does not necessarily imply immunological activity.

Another interesting finding is that most of the reactivity to the MN antigen resides in the IgG4 subclass. This is significant because most of the immunoglobulin that is deposited in the glomeruli of patients with MN is IgG4. However, the serum of several patients also has lesser amounts of IgG1 reactivity to the antigen. This is noteworthy because we believe that the podocyte injury that occurs in $\mathrm{MN}$ is complement-mediated $[8,9]$, and IgG4 does not fix complement; however, IgG1 does. We have also obtained repeat samples from a few patients with $\mathrm{MN}$ and found that the presence of the antibodies corresponds to disease activity in that they disappear during drug-induced or spontaneous remission and reappear with relapse. These findings have clear implications for the diagnosis of idiopathic $\mathrm{MN}$ and for monitoring the response to treatment.

\section{Acknowledgements}

I would like to end by acknowledging the contributions of Larry Beck Jr, and Ramon Bonegio, two junior faculty members without whom this work would not have been completed; the encouragement of Bill Couser; and the cooperation of the New England Organ Bank by providing us with kidneys; as well as the families of the deceased donors and blood donors.

\section{KARGER}

Fax +4161306 1234

E-Mail karger@karger.ch

www.karger.com
(C) 2009 S. Karger AG, Basel

$1660-2137 / 09 / 1121-0011 \$ 26.00 / 0$

Accessible online at:

www.karger.com/nep
David J. Salant, MD

Renal Section, EBRC 504, Boston University Medical Center

650 Albany Street

Boston, MA 02118 (USA)

E-Mail djsalant@bu.edu 


\section{References}

-1 Couser WG, Steinmuller DR, Stilmant MM, Salant DJ, Lowenstein LM: Experimental glomerulonephritis in the isolated perfused rat kidney. J Clin Invest 1978;62:1275-1287.

-2 Van Damme BJ, Fleuren GJ, Bakker WW, Vernier RL, Hoedemaeker PJ: Experimental glomerulonephritis in the rat induced by antibodies directed against tubular antigens. V. Fixed glomerular antigens in the pathogenesis of heterologous immune complex glomerulonephritis. Lab Invest 1978;38:502510.

-3 Couser WG, Salant DJ: In situ immune complex formation and glomerular injury. Kidney Int 1980;17:1-13.
-4 Kerjaschki D, Farquhar MG: The pathogenic antigen of Heymann nephritis is a membrane glycoprotein of the renal proximal tubule brush border. Proc Natl Acad Sci USA 1982;79:5557-5561.

5 Kerjaschki D, Farquhar MG: Immunocytochemical localization of the Heymann nephritis antigen (GP330) in glomerular epithelial cells of normal Lewis rats. J Exp Med 1983;157:667-686.

6 Debiec H, Guigonis V, Mougenot M, Decobert F, Haymann JP, Bensman A, Deschenes G, Ronco PM: Antenatal membranous glomerulonephritis due to anti-neutral endopeptidase antibodies. N Engl J Med 2002; 346:2053-2060.
7 Debiec H, Nauta J, Coulet F, van der Burg M, Guigonis V, Schurmans T, de Heer H, Soubrier F, Janssen F, Ronco PM: Role of truncating mutations in MME gene in fetomaternal allo-immunization and antenatal glomerulopathies. Lancet 2004;364:12521259.

8 Salant DJ, Belok S, Madaio MP, Couser WG: A new role for complement in experimental membranous nephropathy in rats. J Clin Invest 1980;66:1339-1350.

9 Cybulsky AV, Quigg RJ, Salant DJ: Experimental membranous nephropathy redux. Am J Physiol 2005;289:F660-F671. 